\title{
A Case of AVM (Arteriovenous Malformation) of the Deep Lobe of the Parotid Gland
}

\author{
Hiroyuki Iuchi, Hiromi Nagano, Junichiro Ohori and Yuichi Kurono
}

\begin{abstract}
Arteriovenous malformations (AVMs) of the deep lobe of the parotid gland are relatively rare. It is a structural vascular abnormality with no proliferation of cellular components.

A 63-year-old woman presented to the ENT service with a three-month history of swelling and pain on the left side of the parotid area. Enhanced CT revealed a high density spot and diagnostic angiography revealed a high-flow AVM in the deep lobe of the parotid gland. The operation was performed via the parotid gland approach, and the tumor was removed by transecting the superficial temporal artery and the retromandibular vein without massive bleeding.

Histological analysis of the nodule revealed that the proliferating cellular area was composed of endothelial cells and pericytes in addition to the area of dilated vessels. As mentioned above, it was diagnosed an arteriovenous malformation. The AVM showed no evidence of recurrence on CT imaging at about six months after the operation.
\end{abstract}

Keywords : arteriovenous malformations, parotid gland, pain

\section{References}

1) Jackson IT, Carreño R, Potparic $Z$, et al. : Hemangiomas, vascular malformation, and lymphovenous malformations: classification and methods of treatment. Plast Reconstr Surg 91: 1216-1230, 1993.

2）大須賀慶悟，東原大樹，前田 登, 他：頭頸部 vascular malformation に対する治療戦略 ISSVA 分類に基づく頭頸 部血管奇形の診療の実際. 頭頸部癌 34：393-397, 2008.

3) Mulliken JB and Glowacki J : Hemangiomas and vascular malformations in infants and children: a classification based on endothelial characteristics. Plast Reconstr Surg 69: 412-420, 1982.

4) Hosoda Y, Yamashita T, Iwano T, et al. : Arteriovenous malformation in the parotid region; a case report. Pract Otol (Kyoto) 86: 1139-1145, 1993.

5）富樫孝文, 佐藤克郎, 富田雅彦, 他 : 頸部動静脈奇形の 3 症例. 頭頸部外 19: 135-140, 2009.
6）末田尚之, 福崎 勉, 市川大輔, 他：目でみる耳鼻咽喉科 耳介から耳前部に生じた動静脈奇形の 1 例. 耳鼻・頭頸 外科 82: 582-584, 2010.

7) Kohout MP, Hansen M, Pribaz JJ, et al. : Arteriovenous malformations of the head and neck: natural history and management. Plast Reconstr Surg 102: 643-654, 1998.

8）吉田和秀, 鈴木正志 : 脈管性腫瘍をどう扱うか 血管自体 の病変 頭頸部の動静脈奇形. JOHNS 22: 1643-1646, 2006.

9) Jeong HS, Baek CH, Son YI, et al. : Treatment for extracranial arteriovenous malformations of the head and neck. Acta Otolaryngol 126: 295-300, 2006.

10）黑野祐一，松下 太，茂木五郎：深葉型耳下腺多形腺腫の 切除手術. 口腔咽喉科 8: 187-191, 1996.

11）永田基樹, 井上俊哉, 湯川尚哉, 他 : 耳下腺深葉良性腫瘍 症例の検討一術後顔面神経麻痺を中心に一. 頭頸部外 20 : 279-286, 2011.

12）河田 了, 李 吴哲, 吉村勝弘, 他 : 手術を施行した耳下 腺良性腫瘍 300 例の検討. 日耳鼻会報 115：618-624, 2012. 


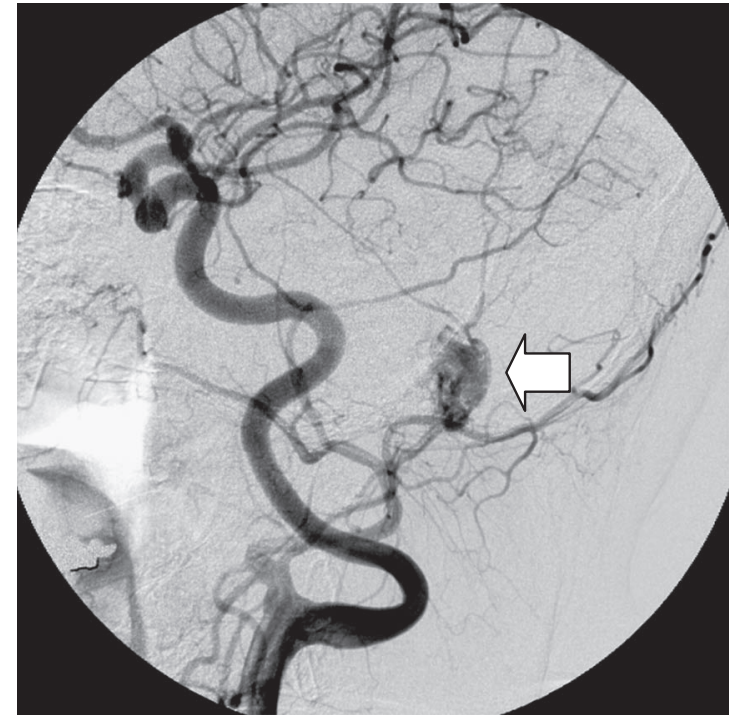

Angiography showing that the feeding artery was the superficial temporal artery.

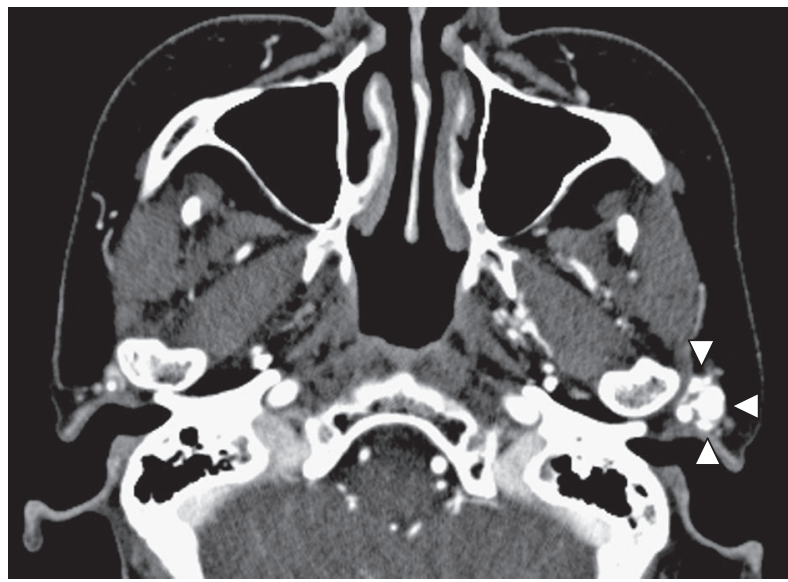

Axial CT scan after enhancement showing a moniliform tumor in the preauricular area (arrow head).

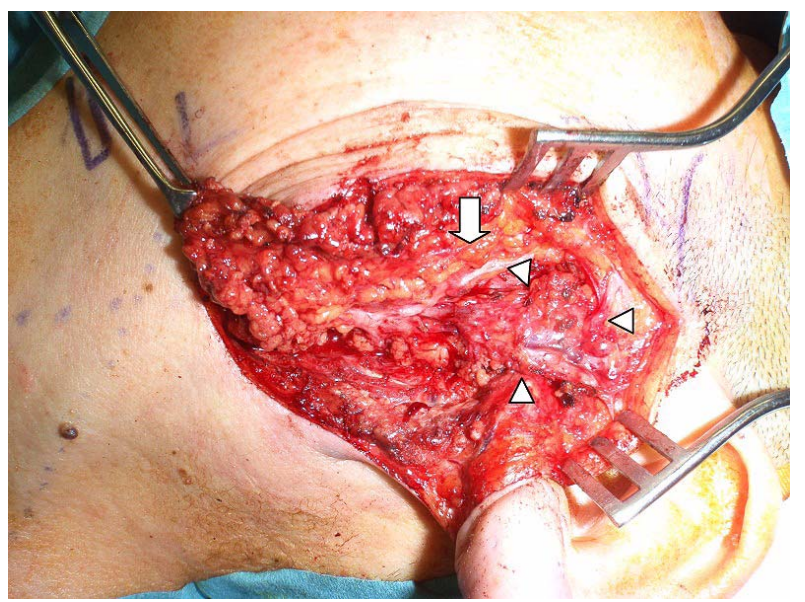

Intra-operative findings. The tumor is positioned in the deep lobe of the parotid gland (arrow head). The arrow indicates the facial nerve. 